DOI: http://dx.doi.org/10.20435/1119

\title{
Symbiotic treatment in hospitalized patients: impact on constipation ${ }^{1}$
}

\author{
Tratamento com simbióticos em pacien0tes \\ hospitalizados: impacto na constipação
}

Sandramara Sasso ${ }^{2}$

Fabiane LaFlor Ziegler Sanches ${ }^{3}$

Rosângela dos Santos Ferreira ${ }^{4}$

Rita de Cássia Avellaneda Guimarães ${ }^{5}$

${ }^{1}$ Acknowledgements to the Programa de Residência Multiprofissional: Atenção ao Paciente Crítico/ PREMUS/UFMS.

${ }^{2}$ Mestre. Universidade Federal de Mato Grosso do Sul. Programa de Residência Multiprofissional: Atenção ao Paciente Crítico/ PREMUS/UFMS. Campo Grande, MS, Brasil. E-mail: sandramara_sasso@hotmail.com

${ }^{3}$ Doutora. Universidade Federal de Mato Grosso do Sul. Campo Grande, MS, Brasil. E-mail: fabianelaflor@gmail.com

${ }^{4}$ Doutora. Serviço de Nutrição. Hospital Universitário Maria Aparecida Pedrossian. Universidade Federal de Mato Grosso do Sul. Campo Grande, MS, Brasil. E-mail: rosangela.ferreira@ufms.br

${ }^{5}$ Doutora. Programa de Pós-Graduação em Saúde e Desenvolvimento na Região Centro-Oeste. Faculdade de Medicina. Universidade Federal de Mato Grosso do Sul. Campo Grande, MS, Brasil. E-mail: rita.guimaraes@ufms.com 


\section{ABSTRACT RESUMO}

The aim of this study was to evaluate the effect of symbiotic treatment on intestinal function in constipated hospitalized patients. The study where with 24 constipated patients of both sexes in a hospital environment were randomized into two groups to receive maltodextrin (control group) and symbiotic treatment (experimental group) daily for 7 days. In relation to defecation frequency, there was no statistical difference between the groups. The percentage of patients who had no evacuation report in the experimental group decreased on days 1 (66.7\%), 4 (41.7\%) and 7 (33.3\%), while the control group did not show such effect. It was found that symbiotic treatment did not lead to an increase in abdominal symptoms in either the experimental or placebo group. The present study showed that symbiotic treatment for 7 days is insufficient to achieve significant results, especially in defecation frequency and stool consistency and shape.

KEY WORDS

constipation prebiotics probiotics
O objetivo deste estudo foi avaliar o efeito do tratamento simbiótico na função intestinal em pacientes hospitalizados com constipação. 0 estudo foi realizado com 24 pacientes constipados, de ambos os sexos, em ambiente hospitalar divididos aleatoriamente em dois grupos, sendo um que recebeu maltodextrina (grupo controle) e outro tratado com simbiótico (grupo experimental) durante sete dias. Em relação à frequência de evacuação, não houve diferença estatística entre os grupos. A porcentagem de pacientes que não tinham relato de evacuação no grupo experimental diminuiu nos dias, 1 $(66,7 \%), 4(41,7 \%)$ e 7 (33,3\%), enquanto o grupo controle não apresentou tal efeito. Verificou-se que o tratamento com simbiótico não contribuiu a um aumento nos sintomas abdominais em ambos grupos, experimental ou placebo. 0 presente estudo mostrou que o tratamento simbiótico por sete dias foi insuficiente para alcançar resultados significativos, especialmente na frequência da eliminação, consistência e formato das fezes.

\section{PALAVRAS-CHAVE}

constipação

prebióticos

probióticos 


\section{INTRODUCTION}

Constipation is a common gastrointestinal disturbance in hospitalized patients, mainly elderly and critically ill patients, who are more likely to develop this intestinal complication in a hospital environment.

Its incidence varies in the literature from 5 to $83 \%$ due to the lack of a consensus on constipation for hospitalized patients. Moreover, the evaluation of the bowel habits in the critical patient is hampered by the use of sedatives, making it difficult to identify gastrointestinal symptoms such as abdominal pain, and the evaluation of stools is difficult and unpleasant in such cases.

Recent studies report that constipation is just not only infrequent defecation (less than 3 times a week). Patients have a wider set of symptoms, including hard stools, sensation of incomplete evacuation, abdominal discomfort, flatulence, distension, and other symptoms as well (excessive straining, sensation of anorectal obstruction during defecation, and need for manual maneuvers during defecation). Constipation has been mentioned as a prognostic factor in the critical patient, and its treatment can lead to a lower incidence of mortality.

Constipation in the hospitalized patient can be associated with a series of factors such as: dehydration, inadequate administration of liquids, changes in the diet linked to the disease or even the lack of fiber in the enteral diet, bedridden situation, immobility or decreased mobility secondary to acute disease, electrolyte disturbances mainly hypokalemia, hypercalcemia and hypomagnesemia, and also medication with sedatives and opioids, and neuromuscular blocking and vasopressor drugs. Furthermore, some medical conditions such as neuropathies, metabolic conditions, myopathies, and mechanical obstructions, among other conditions can also result in decreased intestinal motility. 
This gastrointestinal disorder can lead to multiple complications that go beyond the digestive system, such as vomiting, agitation, obstruction and intestinal perforation, and abdominal distension, which can hamper measures to increase respiratory work, which in critical patients can lead to failure in weaning off mechanical ventilation or to the patient staying longer on it.

In relation to nutritional support, constipation can lead to conditions such as gastroparesis and ileoparesia, which delay the start and hinder progression of the diet or dietary management. Inadequate nutritional support, below the nutritional necessities estimated for the patient may result in a decrease in functional capacity and synthesis of new tissue, increase in number of infections and worsening of prognosis.

The most appropriate treatment for constipation depends mainly on the determination of the underlying causes, although these are often not found. A new therapeutic option for the treatment of constipation is the consumption of probiotics and prebiotics.

Probiotics are defined as live microorganisms that in sufficient numbers alter the intestinal microflora and provide healthful benefits to the host.

Prebiotics are food ingredients that are not digested by intestinal enzymes and favor the selective proliferation and/or multiplication of intestinal microbiota, thus providing benefit(s) to the health of the host.

Symbiotics are products of an adequate combination of prebiotics and probiotics. Therefore, the combination exerts a prebiotic as well as probiotic effect.

The fermentation of prebiotics by the intestinal microbiota results in the production of gases and other products such as short-chain fatty acids (SCFA) mainly acetate, butyrate and propionate. The main bacteria responsible for the production of 
SCFA are of the genera Bifidobacterium and Lactobacillus, also known as probiotic bacteria.

The synthesis of SCFA can improve intestinal motility due to the decrease in intestinal $\mathrm{pH}$. The decrease in $\mathrm{pH}$ reduces the growth of potentially pathogenic bacteria and has an osmotic effect in the colon. This effect is promoted by fatty acids and can increase the absorption of minerals and stimulate peristalsis and consequently intestinal motility.

Accordingly, the aim of this study was to evaluate the effect of symbiotic treatment on the intestinal function of constipated hospitalized patients.

\section{MATERIALS AND METHODS}

\subsection{Study design}

A clinical randomized controlled and blinded trial was conducted, which included patients who were hospitalized in the infirmary of the medical clinic and the intensive care unit (ICU) of Hospital Universitário Maria Aparecida Pedrossian (HUMAP/ EBSERH), Campo Grande, MS, from October to December 2014, over 18 years old, of both sexes, constipated in the hospital, and were on oral and/or enteral feeding. The exclusion criteria were: patients with clinical diagnosis of severe acute pancreatitis, severe sepsis, allergy to any ingredient of fiber supplements and dependence on laxatives, and also patients who were totally unable to use their gastrointestinal tract. The constipated patient was defined as one who showed symptoms according to the Guarner et al. (2011) as mentioned above. This project was approved by the Committee on Ethics in Human Research of the Federal University of Mato Grosso do Sul, $\mathrm{n}^{0}$ 818,641, October $03^{\text {rd }}, 2014$. 


\subsection{Treatments}

The participants were randomized into two groups of independent of feeding route, namely oral or enteral route: control group (placebo) and experimental group (symbiotic treatment). The control group was given maltodextrin and the experimental group LACTOFOS ${ }^{\circledR}$ for symbiotic treatment. Both groups were given doses of $12.0 \mathrm{~g}$ for 7 consecutive days.

For the patients who received oral nutrition, both maltodextrin and LACTOFOS were diluted in fruit juice and offered to the patients with a light meal. The patients who had a nasogastric tube for nutrition, maltodextrin and the symbiotic were diluted in the enteral diet preferably in the first feeding of the day, with intermittent gravitational administration, where infusion flow was controlled by the team, only driven by gravity via the nasogastric tube.

LACTOFOS $^{\circledR}$, which contains per portion of $6.0 \mathrm{~g}$ (1 sachet) $6.0 \mathrm{~g}$ FOS (prebiotic) and 109 colony forming units (CFU) of beneficial bacteria (probiotics) of the strains Lactobacillus paracasei (Lpc-37), Lactobacillus rhamnosus (HN001), Lactobacillus acidophilus (NCFM) and Bifidobacterium lactis (HN019).

\subsection{Assessment of the intestinal functionality}

Response to treatment was evaluated using a daily record of defecation (defecation frequency and stool consistency and shape, in accordance with the Bristol scale) and abdominal symptoms (nausea, vomiting, abdominal pain, abdominal distension and flatulence).

The Bristol scale classifies stools into seven categories: type 1 , separate hard lumps, liked peanuts (difficult to pass); type 2, sausage-shaped, but segmented; type 3 , sausage-shaped, but with cracks on the surface; type 4: sausage- or snake-shaped, smooth 
and thin; type 5: soft pieces, with clear-cut edges and easy to pass; type 6: aerated pieces, with frayed edges; type 7: watery, without solid pieces (LEWIS; HEATON, 2007).

\section{STATISTICAL ANALYSES}

The association between patient gender and the group to which they belonged was evaluated by the Fisher exact test. The Mann - Whitney test was used to analyze the differences in time of last evacuation and the symptoms related to constipation at the time of randomization of the patients. The Friedman test was performed for comparisons between days 1, 4 and 7 in the same group for the variables related to defecation and the gastrointestinal tract. Other data were presented descriptively. We used the statistics software GraphPad Instat 3.0 for a level of significance of $5 \%$.

\section{RESULTS AND DISCUSSION}

Twenty-four patients participated in this study: 12 in the experimental group, of which $58.3 \%(n=7)$ were women and $41.7 \%(n=5)$ men, and 12 patients in the control group, of which $41.7 \%(n=5)$ were women and $58.33 \%(n=7)$ men. In the study sample, there was no significant difference in gender between the groups $(p=0.68)$.

The mean age of the control group was $62.00 \pm 17.03$ years and of the experimental group $66.83 \pm 15.40$ years. There was homogeneity between the groups in relation to the age of the participants, since there was no significant difference between the groups $(p=0.48)$.

In relation to the time of last evacuation of the participants of the two groups, there was no statistical difference, where it was $5.41 \pm 2.69$ days for the experimental group and $4.58 \pm 1.78$ days for the control group ( $p=0.38$ ) before the date of randomization. 
There was no statistical difference in symptoms related to constipation between the two groups at the time of randomization, except for the variable sensation of incomplete evacuation, since it was not possible to obtain this information in the $75.0 \%$ of the patients in the control group ( $p=0.003)$.

Table 1 - Distribution (\%) of the participants according to symptoms related to constipation at the moment of randomization of the patients

\begin{tabular}{|c|c|c|c|c|c|c|c|}
\hline \multirow{3}{*}{ Variable } & \multicolumn{6}{|c|}{ Number of individuals per group (\%) } & \multirow{3}{*}{$\boldsymbol{p}^{(2)}$} \\
\hline & \multicolumn{3}{|c|}{$\begin{array}{l}\text { Experimental } \\
(\mathrm{n}=12)\end{array}$} & \multicolumn{3}{|c|}{$\begin{array}{l}\text { Control } \\
(n=12)\end{array}$} & \\
\hline & Yes & No & $\mathrm{NI}^{(1)}$ & Yes & No & $\mathrm{NI}^{(1)}$ & \\
\hline $\begin{array}{l}\text { Infrequent defecation (less } \\
\text { than } 3 \text { times a week) }\end{array}$ & 100.0 & - & - & 100.0 & - & - & - \\
\hline Hard stools ${ }^{(3)}$ & 16.7 & 83.3 & - & 16.7 & 83.3 & - & - \\
\hline $\begin{array}{l}\text { Sensation of incomplete } \\
\text { evacuation }\end{array}$ & 16.7 & 83.3 & - & - & 25.0 & 75.0 & 0.003 \\
\hline Abdominal discomfort & 25.0 & - & 75.0 & 16.7 & 8.3 & 75.0 & 0.95 \\
\hline Flatulence & 33.3 & - & 66.7 & 25.0 & - & 75.0 & 0.74 \\
\hline Excessive straining & 33.3 & - & 66.7 & 25.0 & - & 75.0 & 0.74 \\
\hline $\begin{array}{l}\text { Sensation of anorectal } \\
\text { obstruction during defecation }\end{array}$ & 16.7 & 16.7 & 66.7 & 8.3 & 16.7 & 75.0 & 0.79 \\
\hline Distension & 50.0 & 50.0 & - & 25.0 & 75.0 & - & 0.30 \\
\hline Rectal bleeding & 8.3 & 91.7 & - & 8.3 & 91.7 & - & 0.98 \\
\hline $\begin{array}{l}\text { Need for manual maneuvers } \\
\text { during defecation }\end{array}$ & 16.7 & 83.3 & - & 8.3 & 91.7 & - & 0.74 \\
\hline
\end{tabular}

In relation to variables related to defecation and gastrointestinal tract, there were no changes at the different times in the patients of the experimental group or of the control group ( $p>0.05)$. The percentages are given in Table 2 . 


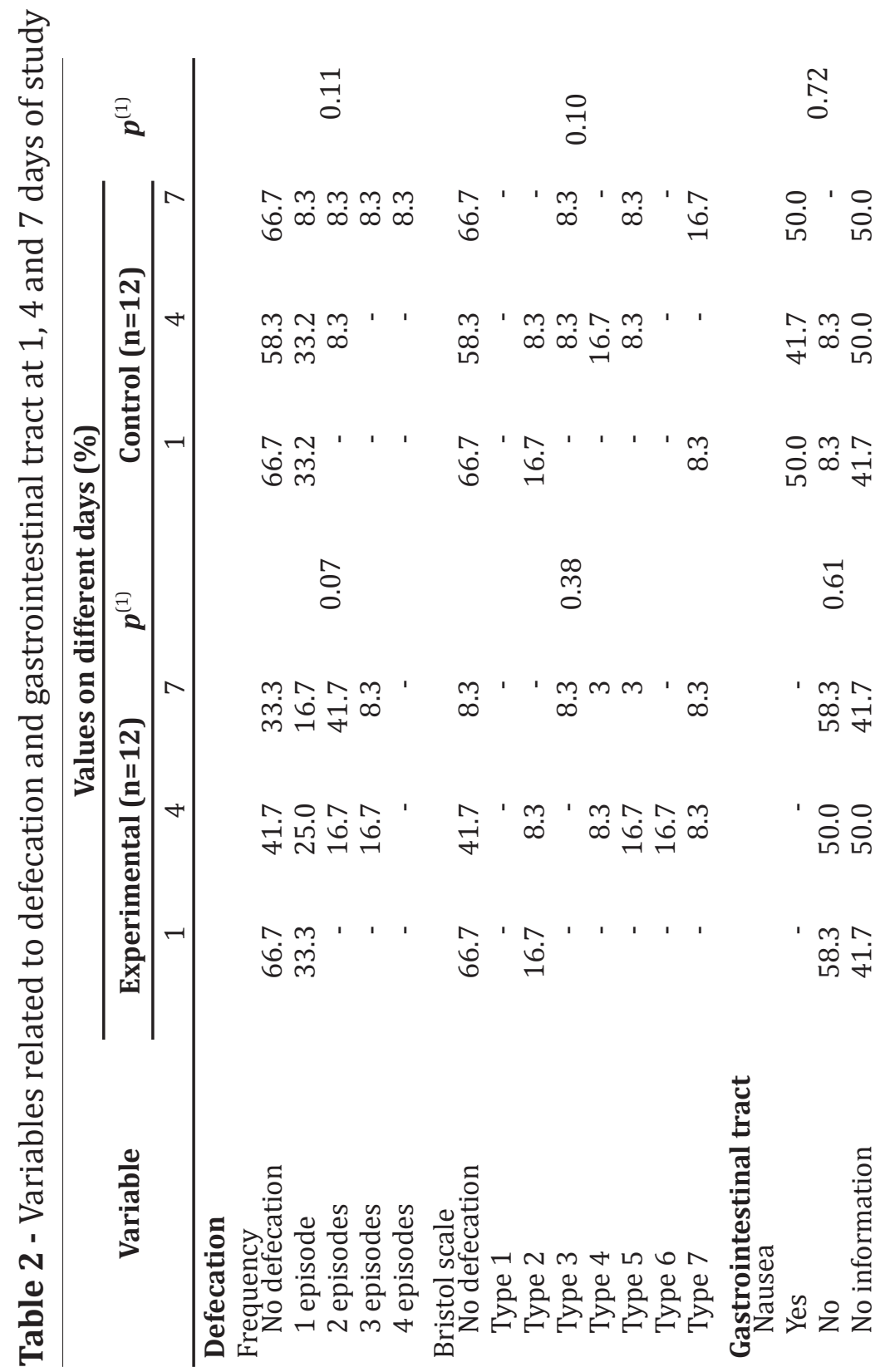


Sandramara SASSO; Fabiane LaFlor Z. SANCHES;

Rosângela S. FERREIRA; Rita de Cássia A. GUIMARÃES

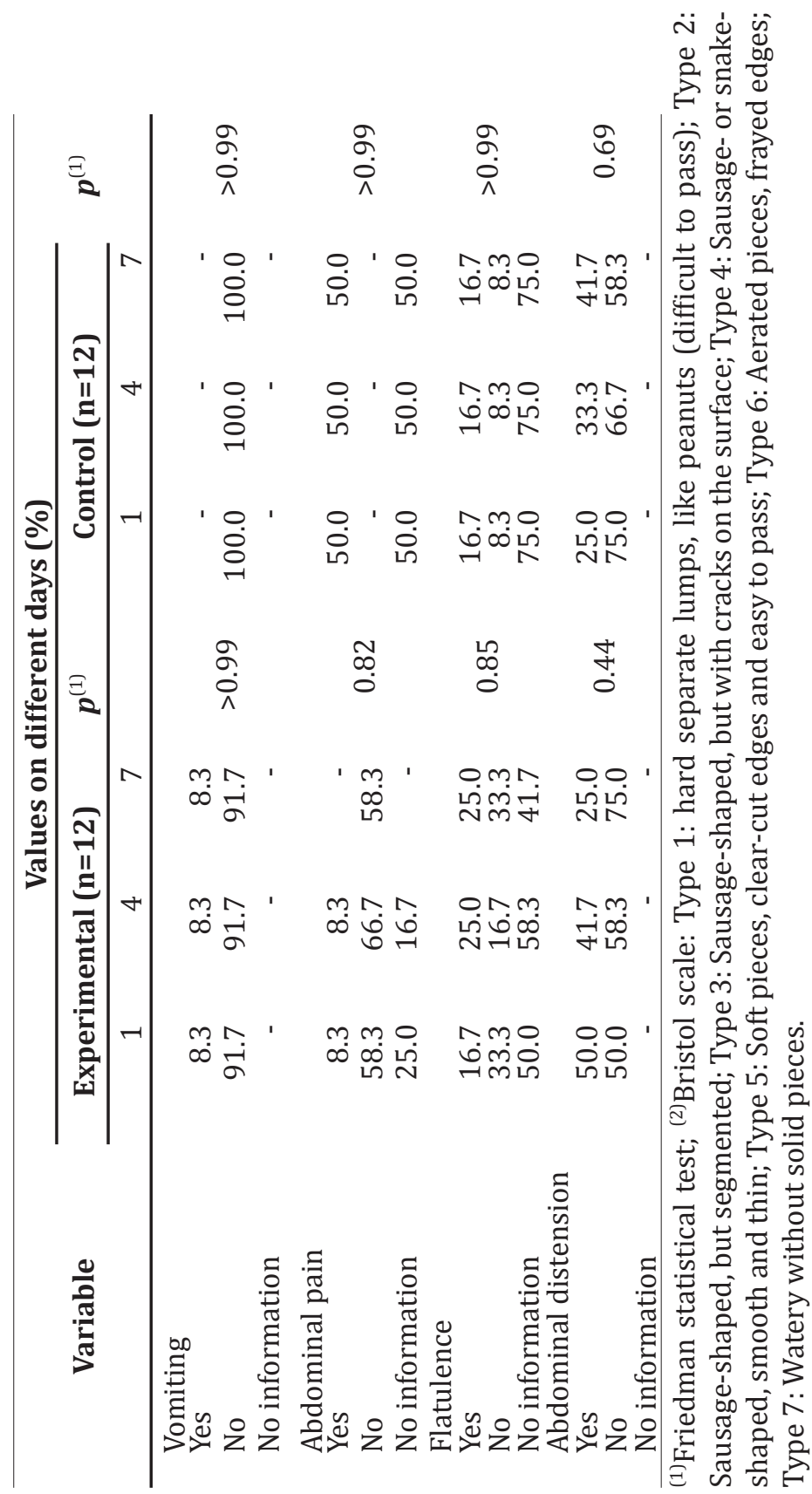


The incidence of constipation in this study was not associated with gender or study group $(p=0.68)$. Similar results were obtained in other studies (GUERRA et al., 2013b; LIU et al., 2015). Nassar, Silva e Cleva (2009) reported a greater incidence of constipation in male patients (64.2\%) in the ICU.

In general, the literature appears to indicate that constipation is more prevalent among the elderly population with a greater incidence in individuals who are older than 65 years or hospitalized or who live in nursing homes due mainly to immobility and chronic medical conditions (MALAGUARNERA et al., 2013; WAITZBERG et al., 2013). In this study, the mean age of the patients corroborated the findings in the literature, where the mean age of the patients of both groups was within the age range considered at risk of developing constipation. Mugie et al. (2011) noted that constipation can affect physical and emotional well-being of the patient. Therefore, the adequate diagnosis and treatment of constipation is essential for a better quality of life of the patient.

In the literature, studies refer to constipation as periods of 3, 4 or 6 days without bowel evacuation, defining this gastrointestinal disturbance by the infrequency in evacuation mainly in critical patients (MOSTAFA et al., 2003; NASSAR; SILVA; CLEVA, 2009; PATANWALA et al., 2006; GACOUIN et al., 2010). Similar results were obtained in our study, with a mean time of last evacuation of 5.41 days in the experimental group and 4.58 days in the control group ( $\mathrm{p}=0.38)$. Gacouin et al. (2010) and Van Der Spoel et al. (2006) found in their studies patients who took $\geq 6$ days to have a bowel movement after being admitted to the ICU. Also, Gacouin et al. (2010) suggested that delayed defecation is associated with a worse prognosis in patients with long-term mechanical ventilation.

In this study, the main complaint related to constipation among the participating patients in both groups was the decrease 
in defecation frequency. Studies in the literature point out that this complaint is prevalent among individuals that report being constipated. However, to define constipation, other complaints should be considered, such as the presence of defecation pain, abdominal pain, and hard, dried stools, besides defecation frequency (LOPES; VICTORIA, 2008). Therefore, health care professionals need to ask more specific questions in relation to the bowel habits of patient whenever possible, to obtain more specific information. Some symptoms related to constipation could not be determined due to the fact that patients were unable to communicate, i.e., under sedation. This limitation compromised the results of this study in relation to the main symptoms of constipation in the hospitalized patient as demonstrated in Table 1 wherein the variable sensation of incomplete evacuation appears with a statistically significant difference between the groups ( $p$ $=0.003$ ), between both, the group control most Patients were sedated and was not possible to carry out the collection of data. Mostafa et al. (2003) reported difficulty in evaluating bowel habits in patients who were sedated and/or in a grave condition, where the evaluation of the stools of these patients was difficult and unpleasant.

It was found that the presence of constipation as well as the symbiotic treatment did not lead to increased symptoms related to the gastrointestinal tract in both groups (Table 2). These data corroborate the findings of Waitzberg et al. (2013). According to Raizel et al. (2011) some individuals may experience a slight increase in the production of gas, abdominal discomfort, colic/abdominal pain and even diarrhea when taking probiotics and prebiotics, which is reversed when they stop taking theses supplements.

It was found that at the end of the study, there was no statistical difference between the control group $(p=0.11)$ and the experimental group ( $p=0.07)$ in relation to defecation frequency 
after 7 days of supplementation with symbiotics. However, it can be seen in Table 2 that the percentage of patients who had no report of evacuation decreased in the experimental group with a comparison between days 1 (66.7\%), 4 (41.7\%) and 7 (33.3\%). In the control group, there was a reduction in the percentage of patients who did not evacuate only at day $4(58.3 \%)$, while the percentages were equal at days $1(66.7 \%)$ and 7 (66.7\%). With a reduction in the variable measuring lack of evacuation in the experimental group, it can be concluded that the continuity in symbiotic treatment for a longer period could lead to a statistically significant result.

In relation to stool consistency and shape as classified by the Bristol scale, there were no statistically significant results in 5 types between the two groups, which can be explained by the short follow-up period for the participating patients of both groups. There are no studies in the literature with characteristics similar to those of the present study, where constipated hospitalized patients were treated with symbiotics.

Fateha et al. (2011) randomized in a clinical trial 66 men constipated adults, where they were divided into two groups, one to receive a mixture of symbiotics and the other a placebo for 4 consecutive weeks. In the first evaluation, after two weeks of supplementation, no significant difference was found in defecation frequency per week between the symbiotic and placebo groups ( $p$ $=0.58$ ), and also, there was no significant difference between the groups in relation to Bristol scale. However, the mean defecation frequency increased significantly in the following 2 weeks in the symbiotic group compared to the placebo group $(p=0.02)$ with regard to improved Bristol scale, mainly in stool size or shape.

Waitzberg et al. (2013) randomized 100 constipated women (Rome III criteria) to receive two daily $12 \mathrm{~g}$ doses of symbiotic (experimental group) or maltodextrin (placebo group) for 30 consecutive days. The women treated with symbiotic showed 
increased frequency of defecation, especially in the second and third week after the start of study. Stool consistency and shape were evaluated by the Bristol scale. These patients had at the beginning of the study parameters considered normal for stool consistency and shape, i.e., sausage- or snake-shaped, smooth and soft (Bristoltype scale of 4). However, even with the increased daily defecation frequency, stool consistency and shape remained normal.

\section{CONCLUSION}

According to the results obtained, symbiotic treatment of constipated hospitalized patients for 7 days was insufficient for significant improvement mainly in defecation frequency and stool consistency and shape.

Further studies are needed to assess symbiotic treatment in this population for a longer period to confirm its effects on this intestinal complication during hospitalization, and even to determine other effects, mainly on the gastrointestinal tract, especially in the critical patient.

\section{REFERENCES}

FATEHA, R.; IRAVANIB, S.; FROOTANC, M.; RASOULID, M. R.; SAADATD, S. Synbiotic preparation in men suffering from functional constipation: a randomised controlled trial. Swiss Medical Weekly, Tehran, v. 30, 2011.

GACOUIN, A.; CAMUS, C.; GROS, A.; ISSLAME, S.; MARQUE, S.; LAVOUÉ, S.; CHIMOT, L.; DONNIO, P.; TULZO, Y. L. Constipation in long-term ventilated patients: associated factors and impact on intensive care unit outcomes. Critical Care Medicine, Rennes, v. 38, n. 10, p. 1933-1938, 2010.

GUARNER, F.; KHAN, A. G.; GARISCH, J.; ELIAKIM; R.; GANGL, A.; THOMSON, A.; KRABSHUIS, J.; LEMAIR, T. World Gastroenterology Organisation Global Guidelines: Probiotics and prebiotics. 2011. Available at: http://www.worldgastroenterology.org/assets/export/ userfiles/Probiotics_FINAL_20110116.pdf>. Accessed 4 January 2015 
GUERRA, T. L. S.; MENDONCA, S. S.; MARSHALL, N. G. Incidência de constipação intestinal em uma unidade de terapia intensiva. Revista Brasileira de Terapia Intensiva, Brasília, v. 25, n. 2, p. 87-92, 2013b.

LEWIS, S. J.; HEATON, K. W. Stool form scale as a useful guide to intestinal transit time scand. Journal of Gastroenterology, London, v. 32, n. 9, p. 920-924, 2007.

LIU, Z.; XU, Z.; HAN, M.; GUO, B. Efficacy of pasteurised yoghurt in improving chronic constipation: A randomised, double-blind, placebocontrolled trial. International Dairy Journal, Shanghai, v. 40, p. 1-5, 2015.

LOPES, A. C.; VICTORIA, C. R. Ingestão de fibra alimentar e tempo de trânsito colônico em pacientes com constipação funcional. Arquivo de Gastroenterologia, Botucatu, SP, v. 45, n. 1, p. 58-63, 2008.

MALAGUARNERA, M.; VACANTE, M.; CONDORELLI, G.; LEGGIO, F.; ROSA, M.; MOTTA, M.; MALAGUARNERA, G.; ALESSANDRIA, I.; RAMPELLO, L.; CHISARI, G. Probiotics and prebiotics in the management of constipation in the elderly. Best Practice \& Research Clinical Gastroenterology, Columbus, v. 25, n. 1, p. 3-18, 2013.

MOSTAFA, S.M.; BHANDARI, S.; RITCHIE, G.; GRATTON, N.; WENSTONE, R. Constipation and its implications in the critically ill patient. British Journal of Anaesthesia, Liverpool, v. 91, n. 6, p. 815-819, 2003.

MUGIE, S. M.; BENNINGA, M. A.; DI LORENZO, C. Epidemiology of constipation in children and adults: A systematic review. Best Practice \& Research Clinical Gastroenterology, v. 25, p. 3-18, 2011.

NASSAR, A. P. JR.; SILVA, F. M. Q.; CLEVA, R. Constipation in intensive care unit: Incidence and risk factors. Journal of Critical Care, São Paulo, v. 24, n. 4, p. 630-639, 2009.

PATANWALA, A. E.; ABARCA, J.; HUCKLEBERRY, Y.; ERSTAD, B.L.; Pharmacologic management of constipation in the critically ill patient. Pharmacotherapy, Arizona, v. 26, n. 7, p. 896-902, 2006.

RAIZEL, R.; SANTINI, E.; KOPPER, A. M.; FILHO, A. D. R. Efeitos do consumo de probióticos, prebióticos e simbióticos para o organismo humano. Revista Ciência \& Saúde, Porto Alegre, v. 4, n. 2, p. 66-74, 2011. 
VAN DER SPOEL, J. I.; SCHULTZ, M. J.; VAN DER VOORT, P.H.; JONGE, E. Influence of severity of illness, medication and selective decontamination on defecation. Intensive Care Medicine, Amsterdam, v. 32, n. 6, p. 87580, 2006.

WAITZBERG, D. L.; LOGULLO, L. C.; BITTENCOURT, A. F.; TORRINHAS, R. S.; SHIROMA, G. M.; PAULINO, N.P., TEIXEIRA-DA-SILVA ML. Effect of symbiotic in constipated adult women - a randomized, double-blind, placebo-controlled study of clinical response. Clinical Nutrition, São Paulo, v. 32, n. 1, p. 27-33, 2013. 